\title{
Ruská literatúra v emigrácii: Ivan Bunin a Vladimir Nabokov
}

\author{
Viera Žemberová (Prešov)
}

Maxim D. Šrajer: Bunin a Nabokov. Príbeh súperenie. Z ruského originálu Bunin i Nabokov. Istorija soperničestva (Moskva, 2013) preložil Miloš Ferko. Bratislava: Vydavatel'stvo Spolku slovenských spisovatel'ov, 2015. Prvé slovenské vydanie. 239 s. ISBN 978-80-8061-868-1.

Na počiatku išlo o literárnovedne koncipovaný tematický okruh zahrnutý do doktorandského štúdia, ktorý neskôr prerástol do sústredeného výskumu, ktorý Maxim D. Šrajer ${ }^{1}$ predkladá vo svojich prácach odbornej a kultúrnej verejnosti ako svoj mnohoročný záujem o tvorbu „dvoch géniov súčasnej literatúry“, Ivana Bunina (18701953) a Vladimira Nabokova (1899-1977) aj v publikácii Bunin a Nabokov. Pribeh súperenia. Šrajerov odborný vklad do spracovania dejín ruskej emigrantskej kultúry a literatúry postupne zapĺňa, aj podla jeho názoru, nateraz prázdne miesta tejto línie autentickej a modernej ruskej kultúrnej minulosti a prítomnosti.

Po prvé ide o literárnohistorické sondy, ktoré sa rekonštrukčne opierajú voči času, zúčastneným autorom a zástupcom spomedzi troch vín rus-

1 „Maxim D. Šrajer (v USA Shrayer) sa narodil v roku 1967 v Moskve. Spolu s rodičmi, spisovatelom Davidom Šrajerom-Petrovom a prekladatelskou Emíliou Šrajerovou-Polakovou, strávil takmer desatročie vo vyhnanstve. V roku 1987 emigroval do USA. Študoval na Moskovskej štátnej univerzite M. V. Lomonosova, na Brownovej univerzite v USA, v roku 1995 získal doktorát na Yalovej univerzite. V súčasnosti pôsobí ako profesor na Boston College“. Vydal autobiografickú knihu Čakanie na Ameriku (2007) a spomienkovú prácu Na odchode z Ruska, beletristické práce Deň zmierenia v Amsterdame (2009), o holokauste Videl som to (2013), tri básnické zbierky, publikuje v prestížnych periodikách. Z literárnovedných prác, popri d’alších, Svet Nabokovových pribehov. Prevzaté z Predslovu (s. 7-11) a O autorovi (229-230) zo slovenského vydania ŠRAJER, Maxim D.: Bunin a Nabokov. Pribeh súperenie. Prel. Miloš Ferko. Bratislava: Vydavatelstvo Spolku slovenských spisovatelov, 2015.

2 Maxim D. Šrajer zvýrazňuje odbornú spoluprácu s Richardom D. Davisom v rokoch 1995-2002, ktorá znamenala získanie, spracovanie a zverejnenie „zaujimavej korešpondencie Bunina s Nabokovom, ktorá trvala vyše dvadsat' rokov" a vyvrcholila „v roku 2002 v kritickom vydani korešpondencie Bunina a Nabokova“, Predslov, s. 10 a Poznámky, s. 181. In: ŠRAJER, Maxim D.: Op. cit., 2015. kej emigrácie v prvej polovici minulého storočia o denníky, korešpondenciu, prevzaté publicistické, odborné a verbálne správy, o dostupné literárne a kultúrne tlače, fotodokumentáciu, autorské rukopisy, osobnú chronológiu, geografiu a získaný archívny materiál. Maxim D. Šrajer ho cieleným štúdiom aj osobnými kontaktmi získal, spracoval, zhodnotil a po mnohoročnej sústrednej pozornosti sa upísal predovšetkým dvom autorom ruskej kultúrnej emigrácie pôvodne v role doktoranda a neskôr literárneho historika.

Po druhé, z literárnovedného výskumu aplikuje Maxim D. Šrajer, popri literárnej histórii, argumentačne spracovanú dobovú literárnu kritiku a kultúrnu publicistiku, čím rekonštruuje a neproblematizuje následky či pôsobenie ruskej kultúrnej inteligencie predovšetkým v európskom medzivojnovom období a v žičlivých centrách pre ruskú emigráciu, teda v Paríži, Berlíne, Londýne a vo Švajčiarsku ako v tých spoločenských lokalitách, v ktorých sa ruská inteligencia dostávala do dialógu s európskym kultúrnym a literárnym životom, pritom si udržala do konca štyridsiatych rokov svojskú, neprenosnú etnickú a tvorivú identity. Maxim Šrajer moment identity zvýrazňuje opakovaným faktom, že literáti a odborná inteligencia publikujú aj v zahraničí v ruskom jazyku v berlínskych novinách Ryl (Kormidlo), v parížskych novinách Vozroždenije (Vzkriesenie), Rossija i slavjanstvo (Rusko a slovanstvo), v parížskom časopise Sovremennyje zapisky (Aktuality) a v newyorskom časopise Marka Aldanova Novyj žurnal (Nový časopis).

Po tretie, autorský a ludský vztah Ivana Bunina a Vladimira Nabokova treba prijat ako metaforu, ba viac univerzum vnášané časom, vývinom, jedinečnostou talentu do kultúre a tvorbe otvorených 
pojmov generácia, tradícia, hodnota, výmena a pohybu. Osobnostný prejav obdivu, neskôr irónie a napokon odmietania patrí $\mathrm{k}$ prejavom mladíckeho individuálneho napredovania a sebavedomia, ktorý môže postretnút, obrazne, práve prepojenie učitel’a a jeho žiaka; čo je ludské, nie je nikomu odopreté a už vôbec nie vzdialené. Maxim Šrajer odvíja svoje sledovanie „príbehu súperenia“ vo vztahu dvoch ruských autorov v emigrácie (Bunin v Paríži - Nabokov v Berlín) od zverejnenia článku Kirilla Zajcera, ktorý 9. novembra 1929 vyšiel v novinách Rusko a slovanstvo pod názvom Svet Bunina a svet Sirina ${ }^{3}$. Šrajer objasňuje, že sa Zajcev nechal na napísanie článku inšpirovat torzom z Nabokovho „románu Lužinova obrana“ a Buninovým úryvkom z „románu Arsenievov život" a „to, že sa názvy oboch úryvkov ocitli na jednej obálke, považoval Zajcev, za priznačne" ${ }^{* 4}$.

Po štvrté, osobnostný, autorský, rodinný a spoločenský príbeh Ivana Bunina a Vladimira Nabokova skladá Maxim Šrajer na podloží časovej osi z dokumentov z viacerých dobových zdrojov, ale predovšetkým dôveruje autenticite výpovedí, zápisov, zaznamenaných postrehov tých d’alších z okolia autorov pre ich citovú, profesijnú či kolegiálnu okolnost', za akej sa ich kontakty utvárali od dvadsiatych po sedemdesiate roky minulého storočia a oni sa pohybovali v ich blízkosti a aké im konkrétna situácia poskytovala možnosti aj príležitosti zapojit sa do riadenia a riešenia problémov, ktoré mali navonok črtu rodinne, príbuzensky, priatelsky a odborne vyvolaných dejov zahrnutých do súhrnu pomenovaného „pribeh súperenia“. Pôdorys osobnej a tvorivej rekonštrukcie „súperenia“ medzi starším Buninom a mladším Nabokovom vymedzil Maxim D. Šrajer literárnohistoricky takto: „Ak neberieme do úvahy letmé zmienky o Buninovi ako o jednom zo spisovatelov, ktori ouplyunili mladého Nabokova, zvraty vztahov týchto spisovatelov boli v povojnozých rokoch predmetom minimálneho záujmu [...]. V predslove $k$ devätzväzkovým zobraným spisom Bunina roku 1965 nazvala Alexander Tuardovskij Nabokova „Buninovým epigó-

3 ŠRAJER, Maxim D.: Op. cit., Úvod. Poetika súperenia, s. 23.

4 Tamže. nom “ [...].“(s. 28). Osobnostne zložitejší v tomto literárnou kritikou vyvolanom vztahu sa javí aj Maximovi D. Šrajerovi práve V. Nabokov, ktorý „Vo svojich autobiografiách, ako aj v interview a korešpondencii amerického a švajčiarskeho obdobia [...] vedome znizilo význam úlohy, ktorú v rozvoji jeho tvorby zohrala literárna societa ruskej emigrácie - a najmä dielo Bunina“ (s. 29). Svoj zámer, rekonštruovat prostredníctvom dostupných a verifikovatelných dokumentov osobného zázemia, pointuje Maxim D. Šrajer dvoma zásadnými reáliami. Tá prvá konštatuje, objektívne „Súčasným bádatelom sa sotva podari úplne zrekonštruovat' úplnú históriu vzt’ahov Nabokova s Buninom" (s. 29), očitých svedkov si zobral čas. Druhá reália naznačuje metodologickú inštrukciu, ktorou sa riadil sám pri utváraní časovej a javovej mozaiky zo vztahu I. Bunina a V. Nabokova, podla nej „Z chronologického hladiska v rámci vztahov Bunina a Nabokova rozoznávame tri hlavné etapy. Prvú od roku 1920 do roku 1933, ked' Bunin ziskal Nobelovu cenu. Druhá etapa trvala približne do odchodu Nabokova za oceán v roku 1940. Bolo to obdobie prudkého vzostupu Nabokova. Stal sa vtedy literárnou hviezdou prvej vel'kosti, zatienil dokonca aj Buninovu slávu. Uzlový bod tretej etapy tvori vznik Buninovej knihy poviedok Temné aleje (1943, 1946). Túto etapu ukončila Buninova smrt'v roku 1953. Aj po nej sa však Nabokov nad’alej vracal $k$ predvojnovým stretnutiam - a aj k Buninovým dielam" (s. 30).

Príbeh autorského súperenia sa odvíja od premien Nabokovho rešpektu voči osobnosti a dielu Ivana Bunina, ale za peripetiou jeho osobných postojov voči hodnotám jeho literárneho odkazu v skutočnosti postáva dobová literárna kritika a kultúrna publicistika pripomínajúca mu Buninovo literárne „otcovstvo“, neskôr vzájomné porovnávanie prevzatých podnetov, striehnutie po ich novej tvorbe a rozličných, aj neliterárnych, detailoch, ktoré by z vôle iných zbližovali, či upevňovali závislost̉ mladšieho na staršom spisovatelovi. Tým prirodzene aj neriadene postupne vznikala, utvárala sa schéma a nakoniec sa stupňovala kultúrna a spoločenská situácia, ktorá ich natrvalo aj neužitočne vtiahla do kolotoča náznakov, odkazov, pocitov, zverejnených názorov ako ruských mužov bez Ruska v neruskej cudzine. 
Táto javová skutočnost’ rozčlenila Šrajerovo pohybovanie sa v genéze a stupňovaní sa „súperenia“ prostredníctvom autentických prameňov - citovanie literárnych častí z autorských textov, citovania zápisov z denníkov, korešpondencie rozličného druhu a pôvodu, uverejňovanie fotodokumentov, osobných a rodinných fotografií, autorského rukopisu, vzájomných venovaní a d’alších osobných i úradných listín - naznačuje, že časová os sa viaže takmer výlučne na autormi zverejňovanú pôvodnú literárnu tvorbu počas ich pobytu mimo krajiny, z ktorej odchádzali do európskej emigrácie. Maxim Šrajer vytvoril seriózne časové a dokumentom vymedzené ihrisko, do ktorého vstúpi konkrétny text a ním získané, overené a zakomponované pohyby, ktoré vyvolali kontakt v komunikácii medzi Ivanom Buninom, Vladimirom Nabokovom, ruskou a neruskou kultúrnou praxou v emigrácii. Dostredivým miestom sporu zostáva aj nie raz pripomínaný Buninov zmysel pre triviálne vtipy a Nabokovo až narcistné zmietanie sa v neustálenom generačnom aj autorskom vztahu $\mathrm{k}$ spisovatelovi Buninovi vo svojom ranom literárnom období, ktoré prežívalo aj sa aktivizovalo v rokoch ich európskej emigrácie.

Rekonštrukcia pre literatúru azda aj prepychová v roku 1953 kompozične viedla autora publikácie Maxima Šrajera, nielen pre zdôvodnenie periodizačného rozčlenenia ich kontaktu v emigrácii od dvadsiatych/tridsiatych rokov po sedemdesiate roky 20. storočia, na rozčlenené chronologické a tematické časti s netradičnými názvami: Nehodnotte ma velmi prísne... (prvá kapitola), Urážka (druhá kapitola), ...V duchu sa potýkam s Vaším nástupcom (tretia kapitola), ,... Umrela nedialeko Ženevského jazera pri predčasnom pôrode“ (štvrtá kapitola), „...O prozaikovi, ktorého kladiem nižšie než Turgeneva“ (Namiesto záveru) a Poznámky s informáciou o autorovi Maximovi D. Šrajerovi. Zvolené názvy jednotlivých kapitol sa viažu znova na literárne odkazy v tvorbe autorov, čím sa nepriamo stupňuje vnútorná osobná dráma obidvoch autorov.

Ivanovi Buninovi v roku 1933 udelili Novelovu cenu za literatúru, „Samotný Nabokov však Nobelovu cenu nedostal" (s. 174). Bunin nehovoril po anglicky, Nabokova znalost’ angličtiny mu umožnila pôsobit' v po anglicky organizovanom školstve, ba viac, literárne tvorit v tomto jazy$\mathrm{ku}^{5}$. „Nabokova sláva Bunina trýznila“ (s. 96), vyrovnával sa s touto skutočnostou stále častejšie iróniou voči staršiemu literátovi a súčasníkovi (s. 84). V dotykových miestach, ked' sa obídu odkazy na vztah k poetike ruských symbolistov, na odeskú lexiku v prozaickom texte, na oblúbené zakomponovanie zvukov kikiríkania do príbehu, či na protagonistovu výpravu z vidieka na cesty do neznámeho sveta, sa potom pozornost' pristaví pri nepopieratel'nej inšpirácii buninovským rukopisom zachyteným ako „umenie intonácie a rytmu prózy“ (s. 81), alebo ako poznanie premenené na následok sujetového spôsobu, ako sa vyrovnat's etikou smrti (s. 84), či na kompozičné pointy využívané na dramatické strety lásky a smrti. Otvoreným miestom vzájomného autorského strategického odklonu nadalej ostal spôsob odlišného tematizovania telesnosti a sexuálnych iniciácií v próze obidvoch autorov.

Pre jedného i druhého, pre Ivana Bunina a Vladimira Nabokova, ostala ich osobným a hned', ako naznačuje Šrajerova publikácia, najslabším miestom autorská túžba povýšená na životnú tvorivú výzvu, aby len jednému z nich priznala kultúrna obec neopakovatel'nú dokonalost' umeleckej tvorby. Paradoxne, čas, v ktorom si boli tak i onak blízko a nablízku, im to obidvom poskytovala, no i tak to akosi nestačilo na ukončenie súperenia.

\section{prof. PhDr. Viera Žemberová, CSc.}

Inštitút slovakistiky a mediálnych štúdií Filozofická fakulta, Prešovská univerzita v Prešove Ul. 17. novembra 1, 08000 Prešov, Slovensko viera.zemberova@ff.unipo.sk
$5 \quad$ Z nabokovovskej lektúry odkazujeme na monografické práce: BOYD, Brian: Vladimir Nabokov (1991) a CORNWELL, Neil: Vladimir Nabokov (1999) a tematické zborníky editorsky zostavené L. S. Dembom (1967) a A. Fieldom (1986). 